\title{
Editorial Foreword 76.4 (November 2017)
}

\section{Our Cover}

This month's cover illustration is an ethnographic grab shot from the market for images and other sacred goods on the periphery of the Taungbyon Festival outside Mandalay in 2011. Read more about it in the presidential address in this month's issue.

\section{IN THIS IssuE}

Unlike the previous issue, which was made up exclusively of standard research articles and various kinds of book reviews, this one consists of works that belong to various genres. There is, as has long been traditional in November issues, a presidential address delivered at the springtime annual meeting of the Association for Asian Studies (AAS). There is also, as has become conventional in recent years, a pan-Asian forum that evolved out of a set of presentations delivered at a JAS at AAS panel held at that same gathering. In addition, this issue has two "Asia Beyond the Headlines" essays, each of which places the dramatic recent political developments in South Korea into a different sort of perspective, as well as a "Reflections" piece, in this case based, like the one by Sheldon Pollock that appeared in these pages a year ago, on a keynote address given at a scholarly conference that focused on Asia but was not sponsored by the AAS. Rounding out the main body of the issue, ahead of the book reviews, are five research articles, two of which look at the drawing and contesting of borders in Northeast Asia and South Asia, respectively; one of which is a foray into the history of science in China's Republican period (1912-49); one of which focuses on Vietnamese collaborators during World War II; and one of which presents the results of an economist's use of demographic data to illuminate patterns in the state violence that convulsed Indonesia in the mid-1960s.

The issue is a diverse one in many ways other than the genres it includes. For example, though many of the contributors are either historians (including four out of the five authors of the stand-alone articles just mentioned) or anthropologists (the presidential address, "Reflections" essay, and two of the five essays in the JAS at AAS forum are the work of ethnographers), the disciplines of sociology, geography, political science, and, most unusually for this journal in the last two decades, economics are all represented as well. In terms of geographical spread, while South Korea and China get more attention than other parts of Asia, readers will find at least passing references in the pages that follow to Thailand, Vietnam, Hong Kong, Pakistan, Afghanistan, India, and Indonesia. When it comes to topics, migration is the focus of the JAS at AAS forum, but contributors also delve deeply into or at least treat in passing the following subjects, among many 
others: protest and resistance, rituals and ceremonies, medicine and the body, the drawing and contesting of political borders, and authoritarianism and repression.

Opening the issue are Hyejin Kim's “'Spoon Theory' and the Fall of a Populist Princess in Seoul" (the eating implement in the title refers to people born into privilege being described as beginning life with a silver one in their mouths) and JAmIE DoucETTE's “The Occult of Personality: Korea's Candlelight Protests and the Impeachment of Park Geun-hye" (whose title includes a different sort of wordplay). These essays, by a political scientist based in Singapore and a geographer based in the United Kingdom (the location of contributors is yet another thing that makes this issue diverse), offer complementary but distinctive efforts to place the dramatic recent events that resulted in a change of government in South Korea into perspective, a largely national one in the first case and a more comparative one in the second.

Next come two essays by prominent anthropologists, both scholars who are known for the acuity of their insights and who have worked in more than one national setting. The first of these pieces is LAUREL Kendall's AAS presidential address, "Things Fall Apart: Material Religion and the Problem of Decay," while the second is Michael HERZFELD's “Thailand in a Larger Universe: The Lingering Consequences of CryptoColonialism," a "Reflections" essay based on a keynote speech he gave at a Thai studies conference held in Chiang Mai. In the first, Kendall, who is based at the American Museum of Natural History in New York City, moves between Korea, Vietnam, and Myanmar, looking at how the "material decay" of diffuse kinds of "empowered objects" is thought about and handled by shamans and other religious figures. In the second, Herzfeld, who is based at Harvard University, places Thai studies into a comparative and international context by, among other things, noting the parallels between the difficulties scholars working on Greece faced a half-century ago or so, back when that country went through a period of military rule, and the difficulties scholars working on Thailand face now.

Following these two pairs of opening essays comes JAS at AAS: The Flow of Migration beyond the Nation, which begins with a think piece by Duke anthropologist Engseng Ho, "Inter-Asian Concepts for Mobile Societies," and ends with a "Response to Responses" by the same scholar that replies to reactions to his opening essay by the four other contributors to the symposium. Between Ho's two pieces comes the following quartet of essays: "Surviving in a 'Society'-centric World" by RIAN THum of Loyola College of New Orleans, a Central Asianist and historian with interests in South Asia and China as well; "Globalization, Transnationalism, and 'Mobile Societies' from a Sociological Perspective" by University of Michigan sociologist JaEeun Kim; "Hong Kong’s Eurasian 'Web' Viewed through the Lens of Inter-Asian Studies," by M.I.T. historian EMma TENG; and "Revisiting Distant Divides and Intimate Connections in Asia," by University of Pittsburgh anthropologist Nicole Constable, who has worked on both China and Southeast Asia. Each contributor comes at the issue of the way migrations have long linked and continue to link different parts of Asia to each other, but each emphasizes the way that paying attention to movements of people reminds us of the need to continue to work to develop effective strategies for writing about and analyzing standard geographical units-be they regions, empires, cities, or countries-that go against the grain in the sense of pushing back against the temptation to think of these entities as tidy constructs with clear and enduring borders and self-contained histories. 
Closing out the front section of the issue are a quintet of stand-alone essays. The first two of them have little in common, other than a shared concentration on the middle of the last century. "Lines of (In)Convenience: Sovereignty and Border-Making in Postcolonial South Asia, 1947-1965," a work by University of Leeds-based international historian ELISABETH LEAKE and University of Bristol-based environmental historian DANIEL HAINES, examines the actions of elites in Pakistan, India, and Afghanistan as the lines separating newly formed countries from one another were being drawn and contested in the wake of the unraveling of the British Empire. Michigan State historian Charles Keith's "Vietnamese Collaborationism in Vichy France," meanwhile, uses the case of an unusual set of individuals who moved from Southeast Asia to the West during World War II to shine a light on "the colonial dimensions of a process of collaboration too often cast as solely European."

The next two articles take us from South and Southeast Asia to China and Northeast Asia and backward in time. The first of these, Sacred Heart University historian DAVID LuEsinK's "Anatomy and the Reconfiguration of Life and Death in Republican China," explores the significance of work done by Chinese anatomical researchers early in the twentieth century, at a time when dissection was just becoming a common method for advancing medical knowledge in their country. This is followed by University of Maryland, Baltimore County historian Nianshen Song's "The Journey towards 'No Man's Land': Interpreting the China-Korea Borderland within Imperial and Colonial Contexts," which looks at the varying ways that different texts, including an eighteenth-century Jesuit map, and different elites of varying periods and with ties to varying states have defined and laid claim to the area near the Tumen River.

The articles section of the issue closes with Michigan State economist Siddharth CHANDRA's analysis of demographic data associated with the same acts of Indonesian state violence whose fiftieth anniversary was the subject of an "Asia Beyond the Headlines" article that this journal recently ran. In revisiting this topic, in "New Findings on the Indonesian Killings of 1965-66" Chandra argues that we can get a more "comprehensive and systematic picture" of things such as the number of people who died and the places they lost their lives by using census data to complement previous studies that have largely depended on anecdotal evidence, memoirs, and the like. His results are not revisionist, for they reinforce the claims of some influential earlier work on the topic, but add a significant and novel dimension to the understanding of a crucially important event in Indonesia's recent past.

\section{Selected Forthcoming Articles in JAS 77.1 (February 2018)}

The Rise of Xinjiang Studies: a JAS New Author Forum

Rian Thum, Justin Jacobs, Tom Cliff, David Brophy, Kwangmin Kim, and Madlen Kobi 
Bodies of Texts: Women Calligraphers and the Elite Vernacular Culture in Late Chosŏn Korea (1392-1910)

Ksenia Chizhova

Pali Scholarship “in Its Truest Sense” in Burma: The Multiple Trajectories in Colonial Deployments of Religion

Alicia Turner

Pan-Asian Poetics: Tagore and the Interpersonal in May 4th New Poetry GAL GVILI

Modeling the Contested Relationship between Analects, Mencius, and Xunzi:

Preliminary Evidence from a Machine-Learning Approach

Ryan Nichols, Edward Slingerland, Kristoffer Nielbo, Uffe Bergeton, Carson

Logan, and SCOTT KLEINMAN

Elegant and Militarized: Ceremonial Volunteers and the Making of New Woman

Citizens

KA-MING WU

The Politics of Commemoration: Patronage of Monk-General Shrines in Late Chosŏn Korea

Maya STILler

"A Fondness for Military Display": Conquest and Intrigue in South India during the First Anglo-Afghan War, 1839-40

Chandra Mallampalli

From Japanese Soldiers to Chinese Rebels: Colonial Hegemony, War Experience, and Spontaneous Remobilization during the 1947 Taiwanese Rebellion VICTOR LOUZON

What Lies Behind the Earliest Story of Buddhism in Ancient Vietnam?

K. W. TAYLOR 